\title{
The Spread and Reception of Don Quixote in China
}

\author{
Guoen Chen ${ }^{1}$, Hongying Zhao \\ ${ }^{1}$ School of Humanities, Wuhan University, Wuhan, China \\ ${ }^{2}$ School of Foreign Language, Wuhan University, Wuhan, China \\ Email: chenguoen503@126.com
}

Received 15 February 2014; revised 17 March 2014; accepted 18 April 2014

Copyright (C) 2014 by authors and Scientific Research Publishing Inc.

This work is licensed under the Creative Commons Attribution International License (CC BY). http://creativecommons.org/licenses/by/4.0/

cc) $\underset{\mathrm{EY}}{\mathrm{B}}$ Open Access

\begin{abstract}
The reception of Don Quixote in China started in the early $20^{\text {th }}$ century, with its media Japanese literature and Russian literature and its initiating point Chinese social reforms as well as intellectuals' self-reflections on their role. Zhou Zuoren was the very first to make a scientific criticism of the novel Don Quixote while Lu Xun took the lead in exploring the essence of Don Quixote's spirit, defining it as mixing realism with idealism, which would have a negative impact on its readers. Lu Xun was thus inspired to create a character named $A Q$, eternally charming readers. Feiming, as an explorer of the truth of humanity, orientalized Don Quixote's spirit in the form of parody. Don Quixote has become a universal symbol of the human spirit, has aroused the attention of Chinese intellectuals, and has even directly "engaged in" the controversies in the Chinese literary world. By the end of $2^{\text {th }}$ century, translations and research on Don Quixote attained new achievements, Don Quixote again winning recognition as an essential theoretical category in helping researchers in the literary world elaborate on the phenomenon of human spirit.
\end{abstract}

\section{Keywords}

\section{Don Quixote, China, Spread and Reception}

Only a limited number of world-renown literary works have ever been praised as lighting the way to the cultural evolution of human civilization, playing the role of a brilliant torch enlightening the human spirit. The reception of these great writings would not only bless a nation abundantly in culture, but also symbolize the nation's cultural deposits, its spirit and its creativity. For this reason, studying a country's reception history in spreading world-famous masterpieces becomes both the project of comparative literature and an important approach to seeking the growth history of national spirit. Don Quixote by Cervantes can be deemed one of the great works of this kind, and its reception in $20^{\text {th }}$ century China reveals the historical as well as realistic challenges Chinese 
people have encountered, and the heroic responses the Chinese have delivered. In the new century, it is vital for us to clarify the reception history of Don Quixote, trace its cultural source and understand its effects on Chinese literature as a guide to face the future confidently.

\section{Introduction of Don Quixote into China in the Early $20^{\text {th }}$ Century}

Don Quixote came to China in the early $20^{\text {th }}$ century. In approximately 1908, Lu Xun and Zhou Zuo-ren read the German version of Don Quixote in Japan. More than a decade later, Zhou Zuoren was still excited when recalling the time, claiming it as his favorite book, to his mind even more intimate than the novel Water Margin (Zhou, 1987a). Lu Xun treasured this German version, and later tried by every means to obtain such versions as the hardback copy in Japanese and the illustrated edition by Gustave Doré, a French painter, entitled Collected Illustrations about the Life of a Witty and Noble Manchester Don Quixote (including 120 illustrations, published by Joseph Miller Publishing House, Munich, Germany in 1925). Lu Xun also collected another novel by Cervantes, Jealousy of Cazales in Estremenu (Zhou, 1991). It is obvious that Lu Xun admired greatly this foremost literary master of world literature.

The first scientific literary review of Don Quixote was made by Zhou Zuoren in his History of European Literature, published in 1918, which was originally the manuscript of his lectures in Beijing University. He wrote in the book, "Cervantes creates the book to make ironies on the time; namely, he illustrates to the public that those following conventional thoughts find it hard to adapt to the new age. The achievements of this book are exceptional. To be frank, its irony at that society might lose its original color, but the ever-lasting issue in life is embodied in the book, making it fresh and permanent, and nothing could change its value no matter what happens and how long it goes. The events written in the novel, set in the common and true background, demonstrate heroic and fantastic deeds performed by the characters. It is undoubtedly the display of the resentment between reality and fantasy; that is to say, it identifies the conflict between the enterprising spirit of human beings and the earthly world. Don Quixote has met failures from time to time, and his behaviors are ridiculous. However, it is usually the case, we find, that the heroes in ancient times who are also failures at first, have got similar spirit to that of Don Quixote's. Such phenomenon simulates us to mediate deeply and constantly"(Zhou, 1989). Zhou Zuoren pointed out the ironic tone and profound analysis of human nature in Don Quixote. Zhou not only pointed out the unrealistic and impractical activities of Don Quixote but also succeeded in exploring, out of these impractical actions of Don Quixote's, that they expose the conflict between the "enterprising spirit of human beings" and realistic earthliness. Zhou even spoke highly of Don Quixote's "brave but fantastic behavior". It is apparent that, for one thing, Zhou has been affected by the research made on Cervantes and Don Quixote by the western literary critics since the period of romanticism, and that, for another, it incarnates the logical thinking pattern of these pioneering Chinese intellectuals in the early $20^{\text {th }}$ century, who accept influences from abroad, and establish the need for social reforms and changes.

In 1922, Lin Shu, co-editing with Chen Jialin, adapted the translation of the first volume of Don Quixote into ancient Chinese, renaming it Legend of a Magic Knight, which was published by Shanghai Commercial Press. This was the first Chinese version of Don Quixote. On Sep. 9, Zhuoren issued an article entitled "On Legend of a Magic Knight" in Morning Supplement, introducing to Chinese readers Cervantes and Don Quixote. In the writing, he discussed the relationship between Don Quixote and Hamlet. He remarked, "The characters in these two great works are the incarnations of the eternal duality in human beings, which is actually the origin of all the culture in the world. Quixote is the representative of belief and ideal while Hamlet symbolizes suspicion and analysis. One is at the mercy of his enthusiasm and emotions, marching on heroically and acting at whatever cost, following the truth he believes in; the other is relying on reason, criticizing all the happenings in the world, believing himself to be the only one he can rely on, but lacking full conviction even in this unique self. Although these two characters are opposites, it is through the mutual supporting of one another that our culture advances progressively." Obviously, the views of Zhou Zuoren in this essay found their source in Turgenev's Hamlet and Don Quixote, but, Zhou Zuoren had his own originality. As Qian Liqun has pointed out, Zhou set forth the thesis of "Don Quixote's Return". After the upsurge of May Fourth's new cultural movement, an urgent question arose over how intellectuals adjusted their value system, defined their historical position and balanced their relations with the ordinary people. At this time, Zhou Zuoren welcomed the "return" of Don Quixote, attaching importance to the complementarities between Don Quixote and Hamlet in helping cultivating sound human nature and culture, as well as the relation between Don Quixote 
and Sancho (the masses). Meanwhile, he took overwhelming the self as "the biggest victory among the victories man hopes to win" (Zhou, 1987b). The desolateness within reflects what Zhou Zuoren has experienced about life, and his "historical introspection and self-reflection on the historical role the new cultural movement of May Fourth and he (and intellectuals alike) played in the new movement" (Qian, 1993).

\section{Lun Xun's Reception}

Lu Xun read Don Quixote when he studied in Japan. In the 1920s, Lu Xun again mentioned Cervantes and Don Quixote (Lu, 1981a) several times when the Zhou brothers were involved in a debate with Chen Xiying, a representative of modern critics. By the end of the 1920s, Creation Society and Sun Society vilified Lu Xun as Don Quxiote in China. From the perspective of $\mathrm{Lu}$ Xun, these people understood neither Chinese society nor the spirit of Don Quxiote in Spanish literature. Therefore, he earnestly requested that Yu Dafu translate into Chinese the German version of Turgenev's Hamlet and Don Quxiote; the translation issued in June 1928 in the Opening Number of "Torrent (Benliu)", a magazine he edited together with Yu Dafu. He even planned to publish a translated version of Don Quxiote in 1929 in the Collection of Dawn Flowers series brought out under his general editorship. Though he failed to achieve the goal, he still had the expectation that, "sometime in the near future, a readable version is available in China" (Lu, 1981b).

$\mathrm{Lu}$ Xun is related to Cervantes in more than this aspect. Before Lin Shu and others alike carried out the publication of Legend of a Magic Knight, Lu Xun had already created The True Story of AQ, a Don Quxiotic novel. These two famous masterpieces contain similar features in various significant respects, so there is no denying the connection between the two.

$\mathrm{Lu}$ Xun, as a sensible realist, is ideologically characterized by distinguishing the boundary between the ideal and reality. He would not believe in the promise of a "golden world" credulously, nor would he advocate nihilism, insisting instead on forging ahead on untraveled roads. He stated his strong objection to various means of self-deception, claiming that such practice is to make up spiritual "escape" by way of "concealing and cheating", "verifying the national features as being pusillanimous, sluttish and sly, while at the same time self-contented; namely, degenerating day by day but always feeling glorified and honored" (Lu, 1981c). Lu Xun's views regarding a clear distinction between the ideal and reality, as well as that between the transoceanic and eastern thinking reflect his real understanding of the essence of Don Quixote's spirit. The spirit of Don Quixote actually is two-sided. On one hand, it reveals one's perseverance in pursuing his goal. On another, he frequently indulges in spiritual aberration, confusing the fantastic world of the mind with that of real social life. $\mathrm{Lu}$ Xun applauds the former whereas he highlights the negative aspects in the spirit, reckoning it mental anesthetics. These severe criticisms of Lu Xun's find root in his own bitter experience and profound observations of the morbid national character of the Chinese, for the sake of fulfilling the historical program of "transforming the national character". With the aim of tearing off the mask of self-deception, severing the spiritual escape of "concealing" and "cheating", and forcing the Chinese people to "open their eyes", Lu Xun created the character AQ. AQ meets failure in real life but succeeds in his own fantastic world, such separation and mixture between the subjective and the objective worlds being typical of the spiritual aberration of Don Quixote. Some have noticed the mental link between AQ and Don Quixote: "Dong Quixote and AQ, the two are popular among the intellectuals. We often hear ironic and scolding words like 'You have fully the AQ spirit.' 'What about you? You are Dong Quixote'. Here we find the two are juxtaposed. Really, people usually connect Dong Quixote and AQ together 'subconsciously"' ( $\mathrm{He}, 1941)$. Apparently, individuals mainly put Don Quixote and AQ in parallel when the objective is segregated and confused with the subjective. When approaching the 1980s, some scholars still focus on such a relation between the two (Guang Dong Study of Lu Xun, 1992).

However, great writers create their characters not only reflecting the universality of human nature, but also revealing their discovery of the unique national spirit. As Zhang Mengyang pointed out, AQ and Don Quixote are brothers in spirit, but they are profoundly different by nature. Don Quixote can be classified as one acting aggressively in "rash advance", completely intoxicated by subjective fantasy. He charges with full confidence against the imagined enemy, his courage mounting as the battle progresses without thinking of retreating and giving up at all. On the contrary, AQ should be categorized as one "withdrawing inwardly". Whenever he encounters troubles, he would flinch, belittling himself and lacking self-confidence. Even if he were driven to the verge of desperation, he would not fight back; instead, he would only "slap and hit himself" (Zhang, 1991). This phenomenon indicates that the negative nature of traditional Chinese culture has branded the character AQ. In 
other words, AQ has developed the spirit of Don Quixote negatively, which indicates that according to Lu Xun, Chinese people, especially Chinese peasants, have formed the habit of self-deception, living in their own subjectively fantastic world, afraid of facing the reality, and even reduced to the status of slaves in the practical world. AQ's spirit is the incarnation of the incorrigibility of Chinese nationals. In contrast, the insane Spanish knight, apart from mixing the imaginative world with the realistic one, is actually endowed with an active enterprising spirit, perseverance in pursuing his ideal and the passion and the will to devote himself to realizing his goal.

\section{Influence on Feiming}

In the modern history of Chinese literature, besides Lu Xun, Feiming has also been affected by Don Quixote in his fictional creations. Different from Lu Xun, who explored and dissected Chinese Don Quixote, utilizing Hamlet's skepticism and maintaining the stance of radical enlightenment, Feiming orientalized the spirit of Don Quixote through parody, projecting him as one who seeks the true essence of life.

Most of Feiming's writings before the 1930s had been set in the tranquil and harmonious countryside, presenting affable old men, innocent children, people who were contented and happy, living an idyllic life. In 1932, Feiming published an autobiographical novel The Story of Mr. Anonymity (Mo Xu-you), which bore a completely different style. Feiming wove the story from his personal experience about the time when he chose to live in the Western Hill, Beijing in the winter of 1927. Admittedly, it was not a common autobiographical novel, as Feiming blended in it a great many fancies, making it miraculously difficult to understand, the characters being partly genuine and partly sham, true as well as false, feigning madness and acting like an idiot, pretending to be potty as well as insane.

It is obvious that The Story of Mr. Anonymity (Mo Xu-you) was influenced by Cervantes's Don Quixote. In his novel there is a passage depicting Mr. Mo Xu-you, on his way to climb the Western Hill, suddenly recalling the Spanish knight Don Quixote. He had the idea he was really like the knight in the medieval period, only that the horse had turned into a donkey, and "Sancho" was absent. Mr. Mo Xu-you once proudly told his landlady he had taken with him "two great books, one is by Shakespeare in Britain, another by Cervantes in Spain". Feiming himself actually commented directly on Cervantes and Don Quixote, imparting why he created Mr. Mo Xu-you, "The person who excels in writing is probably a whiz in life, buffeting his way through the waves, bearing all kinds of humiliations and bitter hardships, testing his ability to live through all sorts of deprivations. He must be a 'vagrant', living where there is water and grass...Turgenev said Cervantes's Don Quixote is the representative of [the] idealist, ...but my view is just the opposite. I find him a real 'experimentalist', delivering a monkey show to us" (Feiming \& He, 1930). The Story of Mr. Mo Xu-you is just Feiming's "monkey show" making use of real materials to readers to see!

What Feiming admired most in Cervantes is the latter's starting to write a novel without having an outline in advance. Decades later, after the publication of The Story of Mr. Mo Xu-you, Feiming admitted that he profited greatly from it: "This book (referring to Don Quixote) is extremely significant, at least for me, in that the book was not completed based on a plot. According to me, it is superior to Water Margin in value" (Feiming, 1985). Cervantes had no detailed plans when first creating Don Quixote. He didn't know what would happen after the old knight left home. Even such an important character as Sancho was not in his plan. Only when he heard a shop-owner on the way exclaiming that a knight would travel without a valet accompanying him, did Don Quixote turn back home to fetch Sancho to go on traveling. Cervantes made up the story as he went along and the image of two characters (the master and the manservant) were becoming clarified as the story was developing, with the ending even being ulterior to what the writer originally intended. Undeniably, Feiming was inspired by such a way of creation. When Feiming started The Story of Mr. Mo Xu-you, he also "had no plan in advance". Camel Grass Weekly, which was in the process of making preparations for publication, was in need of a manuscript, so Feiming decided to write a story. The opening paragraph of the first chapter "Name, Age and Birthplace" said, "I am bored, and we are in the process of establishing Camel Grass. I have to write articles, so I think I had better start writing my Story of Mr. Mo Xu-you." Therefore, he let the meager and eccentric Mr. Mo Xu-you get on his way, riding on a donkey, and taking with him a farmer responsible for driving the donkey. The remaining parts of the story were being made up as he went along, and the personality of Mr. Mo Xu-you was unfolding with the story going on, developing from flat to full, and from vague to clear.

In terms of character creation, these two books are essentially similar. Don Quixote and Mr. Mo Xu-you are both men with knightly conduct, right-minded, ambitious and ready with drawn swords at the sight of injustice 
while meanwhile mentally deranged and abnormal. Don Quixote recognized a windmill as a giant, whereas Mr. Mo Xu-you regarded camel as beast. Don Quixote committed to knightly conduct, for the benefit of his Dulcinea, a beauty he fabricated in his mind; Mr. Mo Xu-you suffered from lovesickness, "hoping a gust of wind would sweep him up to a squire's garden, and he was seen by a beauty on the Embroidery Upper-stair; then a classic romance of love between a gifted scholar and a beautiful lady would ensue." Don Quixote often confused the subjective world with the objective one, being credulous about everything, while Mr. Mo Xu-you made a fool of himself from time to time. For example, when the farmer driving the donkey told him that two bandits robbed the farmers, Mr. Mo Xu-you would take everyone in the world for gangsters, and he even regarded the farmers he employed as conspirators. Don Quixote often talked a lot about all the happenings, ready to make a polished speech, which showed that he was learned and insightful. Mr. Mo Xu-you also liked to make a fuss over a trifling matter. When seeing elderly women pee under apricot trees in the garden, he could not help but copiously quote authoritative works continuously. While noticing the beautiful scenery out of the window in the men's room, he would speak at great length, exclaiming, "leisurely catching sight of the South Mountain". All these reflect Feiming's parody of Don Quixote.

Feiming parodied Don Quixote's behavior, but in so doing what he conveyed was his own understanding of life. Feiming's good friend, Bian Zhilin, recalling those days 20 years later, wrote: "The Story of Mr. Mo Xu-you appeared to be written smoothly; however, it was actually not done without effort, and going vaguely and boundlessly anywhere. Feiming admired the life style of the literati in the Wei-Jing dynasties; he himself could not act accordingly, so he ran unbridled and presumptuous with his pen...Feiming's 'sorrow' was still "limited" at the time(i.e., his writing rambling without criticizing the current malpractice), and yet he had his 'pages full of fantastic talk, penned with bitter tears"' (Bian, 1985). Feiming chose to live in the Western Hill in the winter of 1927, to protest against Zhang Zuolin, who dismissed Zhou Zuo-ren from teaching in Beijing University. He hoped to retreat with his honored professor, so out of rage he dropped out of the university. However, unfortunately, after he quit school, he could not support himself. Only with economic aid from Zhou Zuoren could he escape from surrendering himself to despair. The tortuous and ridiculous difficulties in those days could never be fully grasped if he were not personally on the scene. This is probably what Bian Zhi-lin calls his "pages full of fantastic talk, penned with bitter tears".

In contrast to Cervantes's Don Quixote, who returned home after waking up from his dream, Feiming's Mr. Mo Xu-you went on his way step by step into mysticism, and what he finally comprehended was Zen Buddhism's "Tao". In the tenth chapter, "Mr. Mo Xu-you writes a diary today",

Mr. Mo Xu-you paced back and forth. He strolled to the North Pole, finding that the earth is round. Mr. Mo Xu-you burst into laughter, looking up at the sky. I am a Zenist! But I would not use an exclamation mark. Then, looking down, he replied badly to a toilet cleaner who rudely asked Mr. Mo Xuyou to leave the narrow winding trail, as he wanted to pass by. And Mr. Mo Xu-you's dog barked at the dung tub carrier, and Mr. Mo Xu-you was frightened and bewildered. Therefore, Mr. Mo Xu-you hurriedly came to greet the common people kindly.

Here, the origin of imagination stemmed from the concept of oriental Buddhism, namely, "emptiness (void of the world of senses)". In this sense, Mr. Mo Xu-you could freely come and go, without any obstacles. In other words, this is the occasion when Mr. Mo Xu-you (Feiming) transformed the objective space-time into a subjective one in the state of realization to truth. He strolled to the North Pole, but his body stayed here, his heart being as clear as a mirror, living nowhere. It seems that all the outer blocks are completely gone. For this reason, this shore is the other shore, and he has attained his "tao" in this earthly life where dog is barking and cock crowing. It is actually the case when Feiming is temporarily oblivious of the frustrations of this world, experiencing the joy of spiritual liberty and eternal life. Zhou Zuoren praised The Story of Mr. Mo Xu-you as "quotations of wise men", pointing out that Feimong was approaching oriental mysticism, "The words in the quotations can be criticized, but hardly the mood-'meditation' be blamed!" (Letters and Books of Zhou Zuo-ren, 1935). But it is just because Feiming took "Buddhist meditation" as the spiritual outlet when trapped in troubled times that his reception of Cervantes's Don Quixote is not as critical as Lu Xun's in the latter's creation of The True Story of AQ under the influence of Don Quixote.

\section{4. "Participation in" Literature and Art Debate in China}

Don Quixote, taken as a universal symbol of human being, draws the attention of Chinese intellectuals, and is even 
directly engaged in the "participation in" the debates in the literary arena of China. In the 1930s, four Chinese versions of Don Quixote (1931,1935,1937,1939 issues) were successively brought out at home, and at the same time a great many articles discussing the spirit of Don Quixote were issued in magazines and newspapers. Heine's analysis of Don Quixote and the famous speech of Turgenev's on Hamlet and Don Quixote were introduced to China just in this period. The popularity of "Don Quixote" was stimulated by the debates of Creation Society and Sun Society with Lu Xun.

Creation Society and Sun Society deemed Don Quixote as an abstract spirit behind the times, referring to Lu Xun, Zhou Zuoren, Ye Shengtao, Yu Dafu as "lingering old men" (Fang, 1981), "lagers in the period of social change" (Feng, 1981), "old knights in the field of literature and art" (Li, 1981), "Don Quixote-like humanitarians." (Feng, 1981), According to them, the epoch had marched towards the stage of proletarian revolution, but Lu Xun was still speaking the humanitarian somniloquy of a May Fourth type, opposing those advanced soldiers of the revolutionary times, just like Don Quixote, ludicrous and lamentable, fighting against the windmill.

Creation Society and Sun Society only interpreted Don Quixote from the perspective of "behind times", which simplifies the spirit of Don Quixote, and minimizes the significance of this artistic type. Actually, Creation Society and Sun Society failed to understand the realistic situation of China, nor could they comprehend Lu Xun fully. They began to repudiate him conceitedly based on their superficial knowledge of proletarian revolution theory. Accordingly, they made the same mistake as Don Quixote who arrogantly fought against the windmill. Even in the midst of this heated controversy, there was someone observing that taking Lu Xun as the target of criticism was completely wrong, and that such practice was itself "Don Quixote's riotous dancing" (Shi, 1981).

Facing denouncement by Creation Society and Sun Society, Lu Xun replied, "In China, presently, some people also talk loudly about 'Don Quixote', but since they haven't read the book, what they say is not right."(Lu, 1981d). Therefore, he earnestly asked Yu Dafu to translate Turgenev's famous speech on Hamlet and Don Quixote, and he himself wrote the "editorial postscript". Based on Turgenev's view, he summarized the spirit of Don Quixote as "marching forward courageously to pursue his ideal, without any frustrations in his mind", in contrast with the spirit of Hamlet as "meditating all the time, and suspecting, thus taking no action at all". He remarked, "Later some others disapproved of those Don Quixotic actions as merely pursuing an ideal, and they set forth the view that those advancing relying on reality were actually 'Marxists"' (Lu, 1981d). Here, $\mathrm{Lu}$ Xun tended to classify Marxism as the third thinking pattern, distinct from those of Don Quioxte's and Hamlet's. This defined model surpassed Don Quixote's idealism and Hamlet's skepticism, integrating Don Quixote's pragmatic character of "marching forward" with Hamlet's rational skepticism and turning them into the practice-based political philosophy and life philosophy by means of advancing bravely while facing reality. $\mathrm{Lu}$ Xun's emphasis on "marching forward" and stress on "facing reality" indicate his own conscious spirit of realism. His mastery of Marxism is substantially more accurate and incisive than those critics who call themselves Marxist.

In the early 1930s, Lu Xun enthusiastically and eagerly introduced to China the play Unbounded Don Quixote, written in 1922 by Lunacharsky, a leader in the Russian art and education arena. Lu Xun translated the first act of the play from a German version, and later begged Qu Qiubai to translate the play from Russian into Chinese. The Chinese version was published in "Big Dipper" in serial, by Shanghai Lianhua Press in 1934. The play by Lunacharsky depicted Don Quixote as an idealist and humanitarian. Don's idealistic and humanitarian principles were in great conflict with the violent revolutionary principles in practice. He found that he had no appropriate place in the revolution, so he continued his wandering helplessly. However, obviously Lunacharsky also thought that Don Quixote's humanitarian ideal of "philanthropy and kindness" contained some rationality, but could only be realized after the revolution won its victory, while revolution contradictorily would only be attained by violence. Therefore, Lunacharsky contrived an intellectual-born revolutionary named Balthazar who said to Don Quixote, "Ah, Don Quixote, you can not be a nationalist in a famine-stricken and bleeding republic. The leaders of such a republic urged that the revolt of the masses would lead to victory by whatever means. They would guide the masses to cross the Red Sea and the river, pass through the big desert, and fight violently to get to their destination. And yet, when we reach the destination, we have to take off the bloody armor. Only then would we come to call on you, poor Don Quixote. We may say to you: come to our tent, help us to build up our country...At that time, you will be a truly unbound Don Quixote" (Lunacharsky, 1954). A Don Quixote embodied with future features must be rejected by realistic politics. This is completely the logic of a revolutionary full of ideal and realistic fighting spirit. It is interesting to note that Lu Xun did not lay emphasis on Lunacharsky's arrangement of Don Quixote's future des- 
tiny, in his long "postscript" to Qu Qiu-bai's Chinese version of the play. Rather, he focused on Lunacharsky's criticism of Don Quixote's weaknesses. That is to say, Don Quixote's humanitarianism is "the happiness of equality among sheep and cows", "often taken advantage of by traitors, to leave the world in the darkness" (Lu Xun, 1954). Meanwhile, Lu Xun gave a balanced defense of Don Quixote, observing, "We can not say Quixote's determination to fight against evil is wrong. Neither can we say his inability to judge himself appropriately is a mistake. What is wrong is his means of fighting, because his confusing views inspire his wrong actions... and moreover it is 'worse than useless'". Apparently, Lu Xun evaluated the spirit of Don Quixote based on the real situation of Chinese revolution and starting from the need of the fight at that time.

\section{The Response by the End of the 20 $0^{\text {th }}$ Century}

Lu Xun awaited a readable Chinese version of Don Quixote, and this expectation was satisfied in 1978. The version Yang Jiang had spent years translating directly from Spanish to Chinese was published by People's Literature Press, after the "Cultural Revolution". The version is faithful to the original book, fluent and elegant. Naturally, it is widely popular among readers. Since then, Don Quixote has come to be known by common readers as well. Moreover, the study of Don Quixote has won great achievements. Apart from single reviews, Qian Liqun finished the creation of a monograph in the early 1990s, entitled Abundance of Pains-Eastward Transfer of Don Quixote and Hamlet (Qian, 1993). The book has linked Don Quixote to Hamlet, centering on the impact of these two worldly artistic figures on Chinese intellectuals in their spiritual journey to Don Quixotic and Hamletic intellectuals. The book also implements the stance of enlightenment, with plentiful insightful discoveries. This shows that "Don Quixote" has become a recurring category for researchers to study the phenomenon of human spirit, and a "common name" constantly embodied with the renewed content of the age. Of course, at a time when western ideology rushes into the artistic and literary arena in China in contemporary society, the influence of Don Quixote is not so glaring. Still, as a world-renown work permeated with modern humanitarian spirit, and an eternal book generalizing the universal spirit of human beings, Don Quixote is internally influential to the literary world as well as the ideological field of the times. And with the new era approaching, this influence will continue.

\section{References}

Bian, Z.-L. (1985). Preface to Selected Works of Feng Wenbing. Beijing: People's Literature Publishing House.

Fang, W. (1981). Finishing Our Literature Revolution. In Selected Editions of Debates on "Revolutionary Literature" (1st vol). Beijing: People's Literature Publishing House.

Feiming \& He, X. (1930). “Mailbox” in Camel Grass (Issue 3). Beijing: Feiming \&Fengzhi

Feiming (1985). Untitled. In Selected Works of Feng Wenbing. Beijing: People's Literature Publishing House.

Feng, N. C. (1981). Art and Social Life. In Selected Editions of Debates on "Revolutionary Literature" (1st vol). Beijing: People's Literature Publishing House.

He, Y. (1941). About Dong Quixote and A Q-and Introduction of "Unbounded Dong Quixote". Shanghai Review, 4.

(1935). Letters and Books of Zhou Zuo-ren. Shanghai: Shanghai Qing-Guang Publishing House.

Li, C. L. (1981). Please Look at the Wild Dance of Don Quixote in China. In Selected Editions of Debates on "Revolutionary Literature" (1st vol). Beijing: People's Literature Publishing House.

Lunacharsky. (1954). Unbounded Don Quixote. tra. Qu Qiu-bai, Beijing: People's Literature Press.

Lu, X. Not Letters. Complete Works of Lu Xun. (Vol. 3). "Flowerless Rose (3 ${ }^{\text {rd }}$ ") (1981a). Complete Works of Lu Xun (Vol. 3). Beijing: People's Literature Publishing House.

Lu, X. (1981b). “Torrent (Benliu)" Editing Postscript. In Complete Works of Lu Xun, Vol. 7. Beijing: People’s Literature Publishing House.

Lu, X. (1981c). On Opening Eyes. Complete Works of Lu Xun, Vol. 1. Beijing: People's Literature Publishing House.

Lu, X. (1981d). Torrent (Benliu) Editing Postscript (1). In Collected Works of Lu Xun (Vol. 7). Beijing: People's Literature Publishing House.

Lu, X. (1954). Unbounded Don Quixote, Postscript. Unbounded Don Quixote. Beijing: People's Literature Press.

Qian, L. Q. (1993). Abundant Misery, The Transfer of Don Quixote and Hamlet to the East. Art Press of the Times.

Shi, Y. (1981). Another Riotous Dancing of Don Quixote's. In Selected Editions of Debates on "Revolutionary Literature" (1st vol). Beijing: People's Literature Publishing House. 
Zhou, Y. (1991). Reflections on Spanish Literature, Study of Lun Xun's Collection of Books. Beijing: Press of China Federation of Literacy and Art Circles.

Zhou, Z. R. (1987a). Cervantes, One's Own Garden. Changsha: Yuelu Press.

Zhou, Z. R. (1989). History of European Literature. Changsha: Yuelu Publishing House.

Zhou, Z. R. (1987b). Legend of a Magic Knight, One's Own Garden. Changsha: Yuelu Publishing House.

Zhang, M. Y. (1991) A Q and Typical Spirit in World Literature, a Paper in "Symposium-Commemorating $110^{\text {th }}$ Anniversary of the Birth of Lu Xun". 